\title{
The use of fixed dose combinations in the treatment of hypertension — resistant hypertension or patient resistant to treatment?
}

\author{
Rafał Ziemiński, Wojciech Rogala, Aleksandra Waszczuk, Grzegorz Dzida
}

Department of Internal Diseases Medical University of Lublin, Autonomous Public Clinical Hospital No 1, Lublin, POLAND

\section{Summary}

Resistant hypertension (RH) is defined as a condition in which blood pressure remains above $140 / 90 \mathrm{~mm} \mathrm{Hg}$ despite the use of at least three antihypertensive drugs, correctly combined and in full doses (including a diuretic). In Poland, the percentage of people suffering from RH is estimated at $10-13 \%$ relative to the total number of patients with hypertension. On the other hand, in recent years we have seen a significant increase in the importance of combination products both in Europe and in the United States. Several studies have shown that therapy that includes an average of 3 antihypertensive agents (in the form of combination products) having different mechanisms of action, such as blockers of the renin-angiotensin-aldosterone system (RAAS) in combination with a calcium channel blocker (CCB) or a diuretic, provides blood pressure control in the majority of patients, not only through increased efficacy and tolerability of drugs, but also owing to the simplification of the therapeutic regimen, which promotes the compliance with medical recommendations. In this paper we present the case of a patient with resistant hypertension, whose blood pressure normalised only after the use of a combination product.

key words: resistant hypertension, combined therapy, calcium channel blocker

Arterial Hypertens. 2015, vol. 19, no. 3, pages: 140-144

DOI: $10.5603 / A H .2015 .0018$

\section{Introduction}

Resistant hypertension remains the cause of many diagnostic and therapeutic problems. In this paper we present the case of a patient suffering from this type of hypertension, who has been treated without effect for 4 years, and who achieved a satisfactory hypotensive effect after the introduction of a fixed dose combination drug in her therapy, in accordance with the latest guidelines of the Polish Hypertension Society (PTNT).

\section{Resistant hypertension}

Resistant hypertension $[\mathrm{RH}]$ is defined as a condition in which blood pressure remains above 140/90 $\mathrm{mm} \mathrm{Hg}$ despite the use of 3 medicines (including a diuretic), correctly combined and in full doses $[1,2]$. In addition, according to some authors, difficulties in lowering systolic blood pressure below $160 \mathrm{~mm} \mathrm{Hg}$ in elderly people should also be classified as resistant hypertension. In Poland, the percentage of people suffering from resistant hypertension is estimated at

Address for correspondence: Grzegorz Dzida, MD, PhD

Chair and Department of Internal Diseases, Medical University in Lublin

S. Staszica 16 (SPSK Nr 1), 20-081 Lublin

tel. +48815327717

e-mail: grzegorz.dzida@wp.pl 
$10-13 \%$ of the total number of patients with hypertension. According to the results of the Pol-Fokus study published in 2015, this percentage reaches nearly $20 \%$. Many authors emphasise the need to distinguish between true resistant and pseudo-resistant hypertension. In the case of true resistant HT, very high systolic blood pressure values are seen, allowing diagnosing grade $3 \mathrm{HT}$. Furthermore, this type of hypertension typically occurs in the elderly, in obese people, with metabolic syndrome, left ventricular hypertrophy, renal, thyroid and parathyroid gland dysfunctions, in patients using non-steroidal anti-inflammatory drugs, corticosteroids or sympathomimetics. Other causes of true resistant HT include excess sodium in the diet, non-taking the diuretic, pain syndromes, stress and smoking or drinking alcohol. In turn, pseudo-resistant HT is mainly associated with non-compliance, improper treatment, white-coat effect, mistakes in BP measurement and pseudo-hypertension [3-8].

\section{Fixed dose combination agents in the treatment of hypertension}

In recent years, both in Europe and in the United States, we can see the growing importance of combination products for the treatment of all types of hypertension, including resistant. They were used for the first time already in the 60s of the last century. So far, in the absence of a therapeutic effect of a drug used in monotherapy, its dose was increased. Unfortunately, in addition to an improved hypotensive effect, this method often increased the frequency of adverse events. According to the latest recommendations, treatment of hypertension should start with combination therapy with two drugs, with possible increase of one or both to the maximum dose $[9,10]$. According to the 2015 PTNT Guidelines, the use of combination products increases the efficacy and tolerability of antihypertensive therapy, and also improves patient compliance $[1,11]$.

\section{Case report}

We present a case of a patient hospitalised at the Department of Internal Medicine, Medical University of Lublin, who suffered from resistant hypertension and who achieved blood pressure normalisation only after the use of a combination product. The 59-year-old patient presented to the Admission Room of the Ophthalmology Department because of pain in the head and eyeball. Blood pressure measured at that time was $220 / 120 \mathrm{~mm} \mathrm{Hg}$; therefore, the patient was referred to the Internal Medicine Department for blood pressure normalisation. Four years earlier, the patient was hospitalised at another centre because of significantly elevated blood pressure values. At that time, blood pressure normalisation was achieved by using: indapamide $1 \times 1.5 \mathrm{mg}$, ramipril $1 \times 10 \mathrm{mg}$, and nitrendipine $3 \times 10 \mathrm{mg}$. In the following years, due to frequent headaches associated with high blood pressure values, the patient had been using nitrendipine up to $30 \mathrm{mg}$ per day plus captopril sublingually as necessary. Periodically she also took furosemide. It is difficult to assess whether blood pressure resistance was "true" or "pseudo", because due to the high professional commitment and lack of care for her health, the woman could be non-compliant. However, during her stay at the Department where she regularly took her medication, blood pressure values still did not improve, suggesting a true resistance. Following admission to the Department, torasemide $1 \times 10 \mathrm{mg}$ was additionally used; however, the antihypertensive effect was unsatisfactory. On the next day after admission to the Department, at 8:00 AM, blood pressure was $150 / 90 \mathrm{~mm} \mathrm{Hg}$, and at 10:30 it was $220 / 130 \mathrm{~mm} \mathrm{Hg}$. Long-acting metoprolol $1 \times 50 \mathrm{mg}$ was added to the patient's medication; as a result, blood pressure decreased to $150 / 90 \mathrm{~mm} \mathrm{Hg}$ at 12:00 PM and $160 / 80 \mathrm{~mm} \mathrm{Hg}$ at 2:00 PM. In the following days, blood pressure values were still unsatisfactory - 150/100 $\mathrm{mm} \mathrm{Hg}$ and 160/100 $\mathrm{mm} \mathrm{Hg}$; hence doxazosin $3 \times 4 \mathrm{mg}$ was added to the treatment regimen. Blood pressure values in the following days were $140 / 80 \mathrm{~mm} \mathrm{Hg}, 160 / 90 \mathrm{~mm} \mathrm{Hg}, 160 / 90$ $\mathrm{mm} \mathrm{Hg}$. The ABPM (ambulatory blood pressure monitoring) method was used to monitor the patient's blood pressure. Mean 24-hour blood pressure was $153 / 80 \mathrm{~mm} \mathrm{Hg}$; for the night interval the mean value was $144 / 76 \mathrm{~mm} \mathrm{Hg}$, and for the day interval it was $158 / 83 \mathrm{~mm} \mathrm{Hg}$. Systolic blood pressure load was $98 \%$, diastolic 54\%, RRSmax $228 \mathrm{~mm} \mathrm{Hg}$, RRSmin 130 mm Hg, RRDmax 127 mm Hg, RRDmin $50 \mathrm{~mm} \mathrm{Hg}$ (Fig. 1, Table 1). As the patient's blood pressure control was unsatisfactory, her antihypertensive therapy was modified. Torasemide, ramipril and nitrendipine were discontinued, and a combination product containing perindopril + indapamide + amlodipine 10/2.5/10 mg was introduced; in addition to one dose of this product taken in the morning, the patient was taking $2 \times 4 \mathrm{mg}$ doxazosin and $1 \times 50 \mathrm{mg}$ long-acting metoprolol. The previously persistent pain of the head and eyeball completely resolved, and blood pressure values in the following days were as follows: $145 / 95 \mathrm{~mm} \mathrm{Hg}, 120 / 80 \mathrm{~mm} \mathrm{Hg}, 120 /$ $170 \mathrm{~mm} \mathrm{Hg}$, and $105 / 65 \mathrm{~mm} \mathrm{Hg}$; moreover, the pa- 


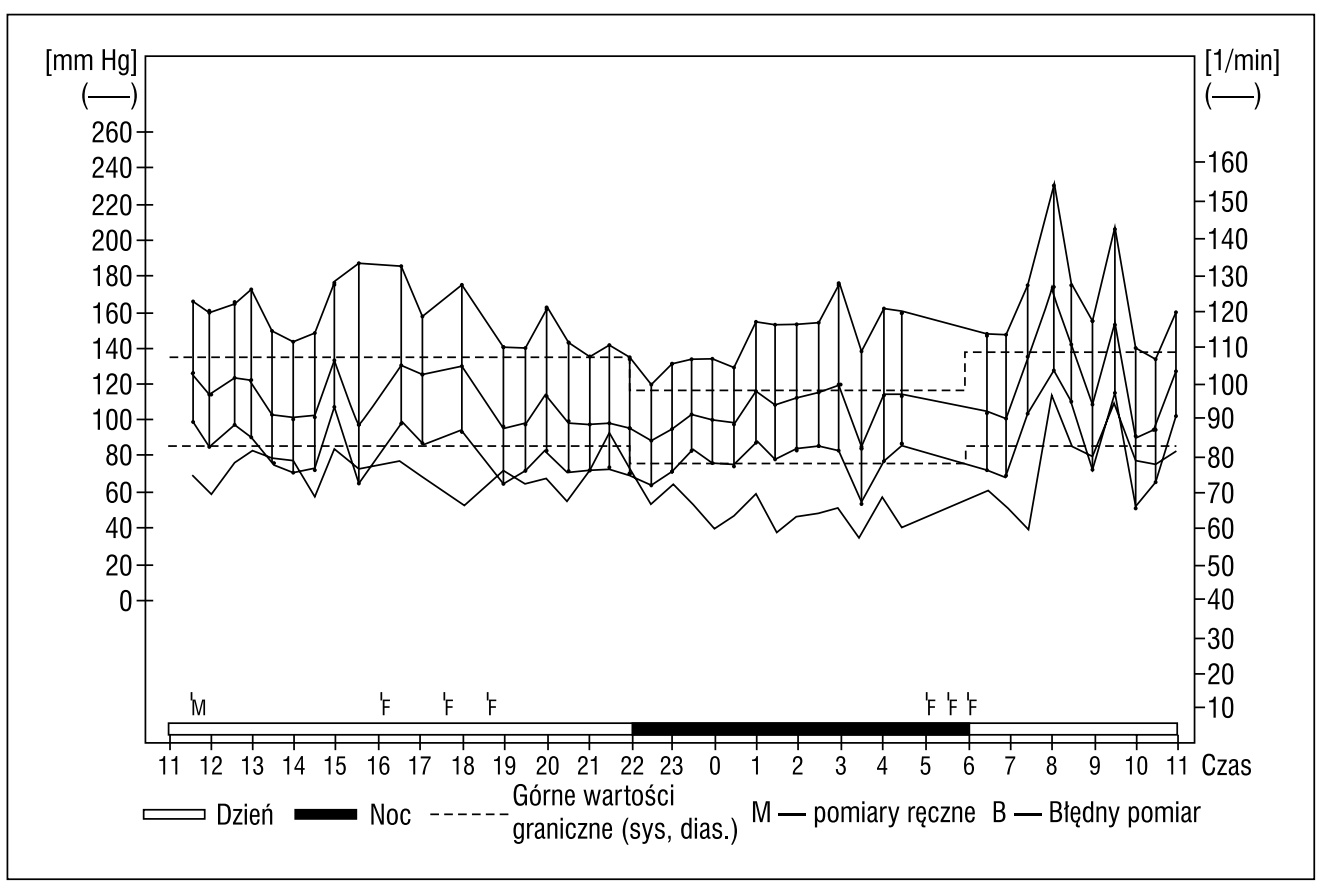

Figure 1. ABPM baseline graph (12/13 May 2015) — see Table 1

Table 1. Collective results of measurements and medications

\begin{tabular}{|c|c|c|}
\hline & ABPM 12/13 May 2015 & ABPM 18/19 May 2015 \\
\hline & \multicolumn{2}{|c|}{$6: 00-21: 59$} \\
\hline MEAN RR, HR & $158 / 83 \mathrm{~mm} \mathrm{Hg}, 76 / \mathrm{min}$ & $112 / 64 \mathrm{~mm} \mathrm{Hg}, 67 / \mathrm{min}$ \\
\hline RRSmin & $130 \mathrm{~mm} \mathrm{Hg}$ & $95 \mathrm{~mm} \mathrm{Hg}$ \\
\hline RRSmax & $228 \mathrm{~mm} \mathrm{Hg}$ & $145 \mathrm{~mm} \mathrm{Hg}$ \\
\hline RRDmin & $50 \mathrm{~mm} \mathrm{Hg}$ & $46 \mathrm{~mm} \mathrm{Hg}$ \\
\hline \multirow[t]{2}{*}{ RRDmax } & $127 \mathrm{~mm} \mathrm{Hg}$ & $83 \mathrm{~mm} \mathrm{Hg}$ \\
\hline & \multicolumn{2}{|c|}{$22: 00-5: 59$} \\
\hline MEAN RR, HR & $144 / 76 \mathrm{~mm} \mathrm{Hg}, 65 / \mathrm{min}$ & $97 / 56 \mathrm{~mm} \mathrm{Hg}$ \\
\hline RRSmin & $118 \mathrm{~mm} \mathrm{Hg}$ & $80 \mathrm{~mm} \mathrm{Hg}$ \\
\hline RRSmax & $173 \mathrm{~mm} \mathrm{Hg}$ & $131 \mathrm{~mm} \mathrm{Hg}$ \\
\hline RRDmin & $52 \mathrm{~mm} \mathrm{Hg}$ & $40 \mathrm{~mm} \mathrm{Hg}$ \\
\hline RRDmax & $87 \mathrm{~mm} \mathrm{Hg}$ & $81 \mathrm{~mm} \mathrm{Hg}$ \\
\hline Daytime/nighttime RRS/RRD (\%) & $8,9 \% / 8,4 \%$ & $13,4 \% / 12,5 \%$ \\
\hline Antihypertensive medications & $\begin{array}{l}\text { Indapamide } 1 \times 1,5 \mathrm{mg} \\
\text { Ramipril } 1 \times 10 \mathrm{mg} \\
\text { Nitrendipine } 3 \times 10 \mathrm{mg} \\
\text { Torasemide } 1 \times 10 \mathrm{mg} \\
\text { Metoprolol ZOK } 1 \times 50 \mathrm{mg} \\
\text { Doxazosin } 1 \times 4 \mathrm{mg} \\
\mathbf{8} \text { tablets/day }\end{array}$ & $\begin{array}{l}\text { Fixed Dose Combination: } \\
\text { Perindopril//indapamide/amlodipine } \\
\text { 10/2,5/10mg; } 1 \times 1 \text { tablet } \\
\text { Metoprolol ZOK } 1 \times 50 \mathrm{mg} \\
2 \text { tablets/day }\end{array}$ \\
\hline
\end{tabular}

RRS - systolic blood pressure; RRD — diastolic blood pressure; HR — heart rate

tient began to complain of orthostatic hypotension symptoms. Doxazosin was discontinued and ABPM monitoring was repeated - mean 24-hour blood pressure was $105 / 61 \mathrm{~mm} \mathrm{Hg}$; for the night interval the mean value was $97 / 56 \mathrm{~mm} \mathrm{Hg}$, and for the day interval it was $112 / 64 \mathrm{~mm} \mathrm{Hg}$. Systolic blood pressure load was $11 \%$, diastolic 3\%, RRSmax $145 \mathrm{~mm} \mathrm{Hg}$, RRSminP 80 mm Hg, RRDmax 83 mm Hg, RRDmin 


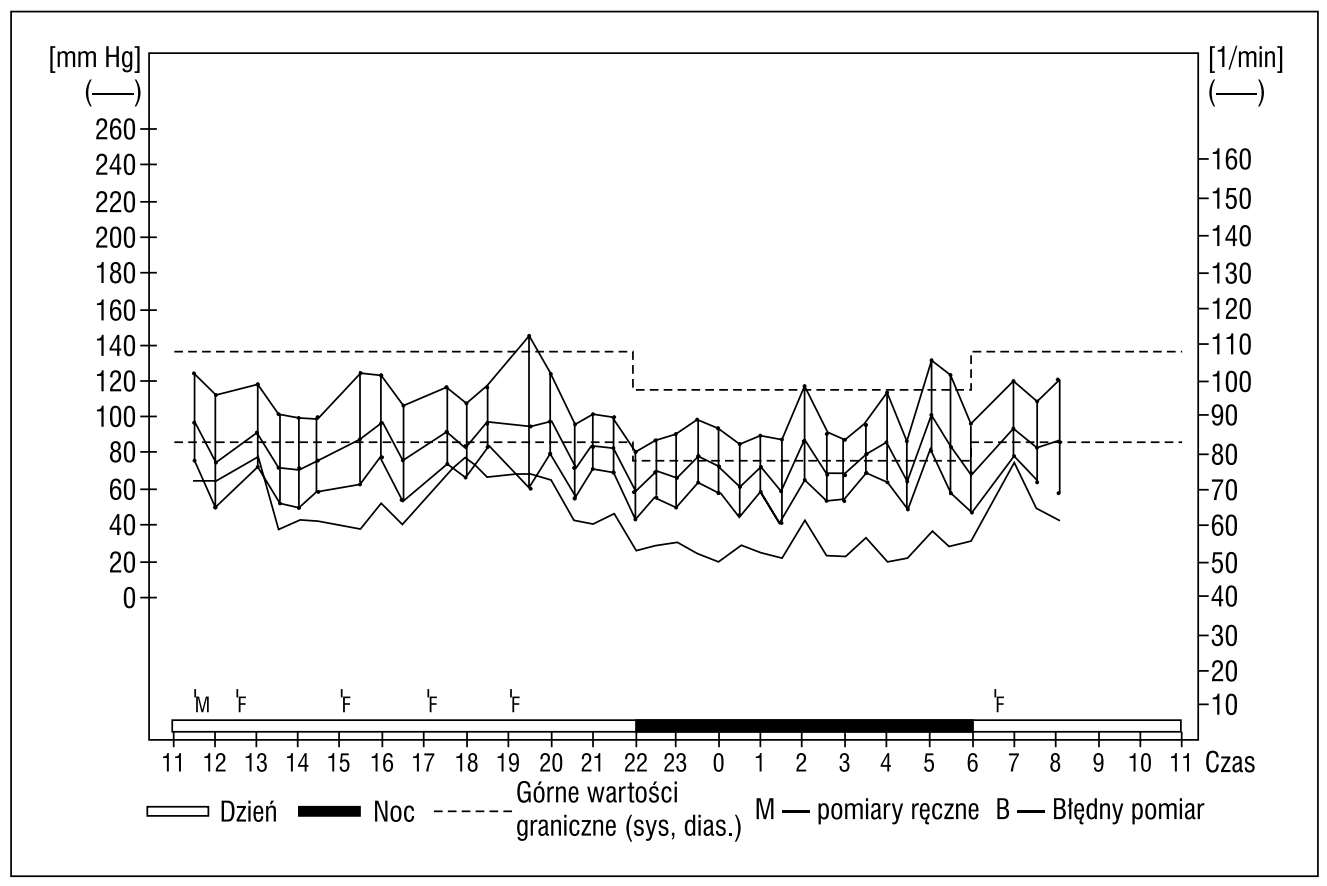

Figure 2. ABPM baseline graph after treatment modification (18/19 May 2015) — see Table 1

$40 \mathrm{~mm} \mathrm{Hg}$ (Fig. 2, Table 1). The woman was discharged home in good general condition, without complaints, with a recommendation to reduce her body weight due to grade 3 obesity (BMI $43 \mathrm{~kg} / \mathrm{m}^{2}$ ), and to take orally the combination product containing perindopril+indapamide+amlodipine $10 / 2.5 / 10 \mathrm{mg}$ once daily, in addition to long-acting metoprolol $50 \mathrm{mg}$ once daily, atorvastatin $20 \mathrm{mg}$ once daily due to abnormal lipid profile, and metformin sustained release $500 \mathrm{mg}$ once daily at bedtime due to impaired fasting glucose (IFG). Currently the patient has satisfactory blood pressure values and she remains under the care of the Cardiology Outpatient Clinic; check-up 30 days after discharge from the Department showed satisfactory blood pressure values.

\section{Discussion}

Several studies have shown that the introduction of an average of 3 antihypertensive agents (in the form of combination products) having different mechanisms of action, such as blockers of the renin-angiotensin-aldosterone system (RAAS), in combination with a diuretic or $\mathrm{CCB}$, in most cases allows to achieve target blood pressure values, which was confirmed in our patient, resulting in a spectacular, or even hypotensive effect, despite prior ineffective use of products with the same mechanism of action, given separately. However, patients with RH and coronary artery disease can also benefit from products which are a combination of a CCB with a beta-blocker.

When deciding to initiate treatment, it should be determined which combination would be the most effective. It should be tailored to the patient's needs. Concomitant diseases, such as diabetes, metabolic syndrome, past myocardial infarction or stroke should be taken into account.

In addition to obvious pathophysiological rationale for the above combinations, their efficacy has been confirmed in clinical trials. An example is the ADVANCE study, which monitored the combination of an ACEI, perindopril, with a thiazide-like diuretic, indapamide. For a period of 4 years, the investigators followed-up a group of randomly selected patients with resistant HT and diabetes who took a combination product and placebo. In the group of patients treated with the combination product, all-cause mortality was reduced by $14 \%$ and cardiovascular mortality by $18 \%$ compared with patients receiving placebo. In addition, the antihypertensive therapy reduced the risk of micro- and macrovascular complications.

Furthermore, the ADVANCE CCB study demonstrated a reduction in overall mortality by $28 \%$ in over 3,000 patients treated with perindopril, indapamide and a CCB.

One of the key studies evaluating the effect of combined perindopril and amlodipine was the ASCOT-BPLA study. Follow-up of the group treated with a combination of angiotensin-converting en- 
zyme inhibitor (ACEI) and CCB showed a decrease in all-cause mortality, cardiovascular mortality and stroke compared with the group receiving atenolol and a thiazide diuretic used as necessary.

Another study, in which three therapeutic strategies were compared, was the STRATHE study. One group of patients was treated with a gradually increasing dose of a combination product containing perindopril and indapamide, the second group was treated with atenolol or losartan alone, and when this treatment failed, the third treatment received a titrated dose of valsartan with addition of hydrochlorothiazide. Also here the best results were obtained for the combination products after 9 months $[12,13]$.

\section{References}

1. Tykarski A., Narkiewicz K., Gaciong Z. et al. Zasady postępowania w nadciśnieniu tętniczym -2015 rok. Wytyczne Polskiego Towarzystwa Nadciśnienia Tętniczego. Nadciśnienie Tętnicze w Praktyce 2015: 1: 32.

2. Calhoun D.A., Jones D., Textor S. et al. Resistant hypertension: diagnosis, evaluation, and treatment. A scientific statement from the American Heart Association Professional Education Committee of the Council for High Blood Pressure Research. Hypertension 2008; 51: 1403-1419.

3. Januszewicz A., Prejbisz A. Oporne nadciśnienie tętnicze. Zasady postępowania w praktyce lekarskiej. Via Medica, Gdańsk 2009.

4. Kaplan N.M. Resistant hypertension. J. Hypertens. 2005; 23: 1441-1444.

5. Williams B. Resistant hypertension: an unmet treatment need. Lancet 2009; 374: 1396-1398.

6. Alderman M.H. Resistant hypertension: a clinical syndrome in search of a definition. Am. J. Hypertens. 2008; 21: 965-966.

7. Szwench E., Florczak E., Prejbisz A., Kądziela J., Witkowski A., Januszewicz A. Oporne nadciśnienie tętnicze - postępy w diagnostyce i leczeniu. Kardiologia Polska 2012; 70: 66-74.

8. Tykarski A. Nadciśnienie tętnicze oporne. Choroby Serca i Naczyń 2005; 2: 190-193.

9. Mann S.J. Drug therapy for resistant hypertension: a simplified, mechanistic approach J. Clin. Hypertens. 2011; 13: 120-130.

10. Moser M., Black H.R. The role of combination therapy in the treatment of hypertension. Am. J. Hypertens. 1998; 11: S73-S78.

11. Gaciong Z., Narkiewicz K., Tykarski A., Filipiak K.J., Opolski G. Miejsce gotowych połączeń lekowych w terapii nadciśnienia tętniczego — stanowisko ekspertów. Nadciśnienie Tętnicze 2009; 13: 363-370.

12. Woźniacka L., Posadzy-Małaczyńska A. Rola preparatów złożonych w terapii nadciśnienia tętniczego. Przew. Lek. 2009; 3: 58-69.

13. Gupta A.K., Arshad S., Poulter N.R. Compliance, safety, and effectiveness of fixed-dose combinations of antihypertensive agents: a meta-analysis. Hypertension 2010; 55: 399-407.

14. Chalmers J., Arima H., Woodward M. et al. Effects of Combination of Perindopril, Indapamide, and Calcium Channel Blockers in Patients With Type 2 Diabetes Mellitus. Results From the Action in Diabetes and Vascular Disease: Preterax and Diamicron Controlled Evaluation (ADVANCE) Trial. Hypertension 2014; 63: 259-264. 